\title{
脚立からの転落災害の現状と防止対策の展望
}

\section{菅 間敦*1}

脚立は業種を問わずあらゆる場所で見かける用具であり, 軽作業で利用される機会が多いが，その使用方法 を誤れば転落などの災害に繋がり，場合によっては死亡に至るケースもある．本研究では，安全な脚立作業の確 立に向けて, 脚立使用中の労働災害に関する統計分析によりその実態を明らかにするとともに，災害発生防止に 向けた取り組みについての提言を行う。特に，脚立上で作業者がバランスを崩して転落するケースが多いこと から, 脚立上での作業時における身体姿勢の不安定性の評価結果に基づいて適切な脚立の使用方法について述 べる.

キーワード : 脚立, 墜落・転落, 災害分析, 作業姿勢計測

\section{1 はじめに}

脚立 ${ }^{1)}$ は高所への移動または高所作業に使用する用具 で，業種や業態を問わず様々な場面で利用されている が, 昨今は脚立使用中に墜落・転落するなどの労働災害 が問題視されている.

脚立使用中の労働災害が多い原因として, 作業中や昇 降時に作業者がバランスを崩して転落することに加え, 脚立自体が倒れやすいということが挙げられる．脚立は 簡便に扱える用具であるが，仮設足場や高所作業車での 作業よりも転倒リスクが高いと考えられる.

また, 作業床の高さが $2 \mathrm{~m}$ 以上の場合は労働安全衛生 規則第 518 条により墜落防止措置等の対策が義務づけら れているが，作業現場でよく利用される高さ $2 \mathrm{~m}$ 未満の 脚立の使用には法的な対策義務がない.そのため十分な 安全対策がなされないまま作業を行い，被害が重篤化す る傾向にある. 加えて, 非定常作業などにもよく利用さ れ，安全対策が十分になされていない場合も多く見受け られる。

このような背景のもと, 本稿では安全な脚立作業の確 立に向けて, 脚立使用中の労働災害（以下, 脚立起因 災害）の発生防止に向けた取り組みについての提言を行 う. 具体的には, 統計分析により脚立起因災害の実態を 明らかにするとともに, 実験研究に基づく脚立への適切 な立ち方について考察する.

\section{2 脚立作業中の労働災害に関する統計分析 ${ }^{2)}$}

脚立の使用に関連する労働災害の実態について調査す るため, 厚生労働省が提供する労働者死傷病報告 ${ }^{3)}$ を用 いて, 平成 18 年（2006年）の休業 4 日以上の災害から単 純無作為法に抽出された 34,195件を対象に分析を行っ た.なお当年の労働者死傷病報告全数は 134,298 件で あったため, 分析対象データの抽出率は $25.5 \%$ である.

原稿受付 2016年11月 1 日 (Received date: November 1, 2016) 原稿受理 2016年12月15日（Accepted date: December 15, 2016） J-STAGE Advance published date: January 23, 2017

*1 労働安全衛生総合研究所 リスク管理研究センター

連絡先：干204-0024 東京都清瀬市梅園 1-4-6

労働安全衛生総合研究所 リスク管理研究センター 菅間 敦

E-mail: sugama@s.jniosh.go.jp

doi: 10.2486/josh.JOSH-2016-0010-SHI
分析方法は，労働者死傷病報告に記載された「災害発 生状況及び原因」の欄に記述された文章と，「脚立」に関 連する語句の一致検索を行い，抽出した事例を一次抽出 した。なお，脚立以外の「足場」や「踏み台」に関連する 語句は検索対象としなかった。その後，被災状況を精読 し, 脚立が災害発生原因の直接的な原因ではないと判断 したものを除外し，二次抽出結果を「脚立起因災害件数」 と定義した。 そしてこの值を分析対象データの抽出率で 割り，その年の年間発生件数を求めた。年間発生件数は 推定の誤差を含むため，95\%信頼区間（以下，95\%CI） としてばらつきの範囲を求めた。

分析の結果，非死亡災害986件と死亡災害6件の合計 992 件が脚立起因災害として抽出された。これを 1 年間 あたりの災害件数に換算すると, 死亡災害が年間 4 件, 非死亡災害が3,896件（95\%CI: 3,657～4,135） 発生して いると考えられた。

抽出された災害事例を分析したところ，被災者の性別 は男性が 881 件で $88.8 \%$ ，女性は 111 件で $11.2 \%$ であっ た。業種別に見ると，図1のように，建設業が最も多く $45 \%$ 占めていた。次いで製造業の $16 \%$, 商業の $12 \%$ の 順に多いことがわかった。

図 2 に被災者の休業予測日数について日数別の構成比 を示す．この結果をみると，休業31～60日の被災者が 約 $30 \%$ と最も多く，休業 1 力月以上の被災者が全体の 65\%以上を占めていた。このことから脚立からの転落 時に負傷することで，長期的な休業に至る可能性が高い

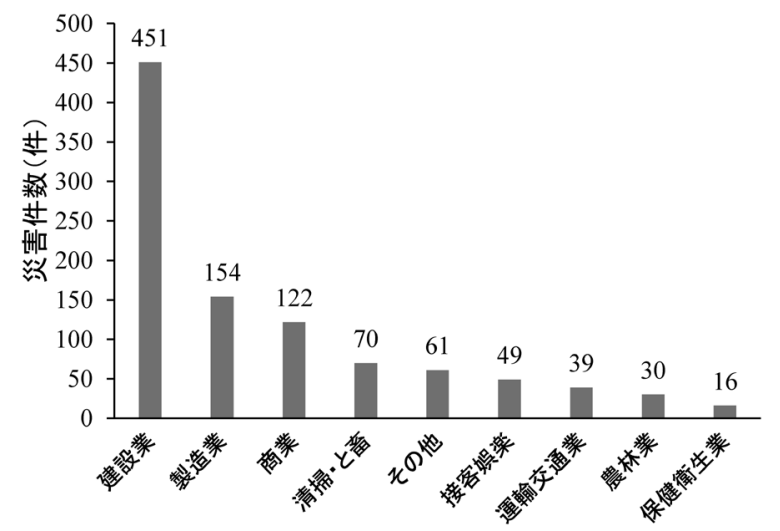

図 1 脚立起因災害の業種別の構成比 


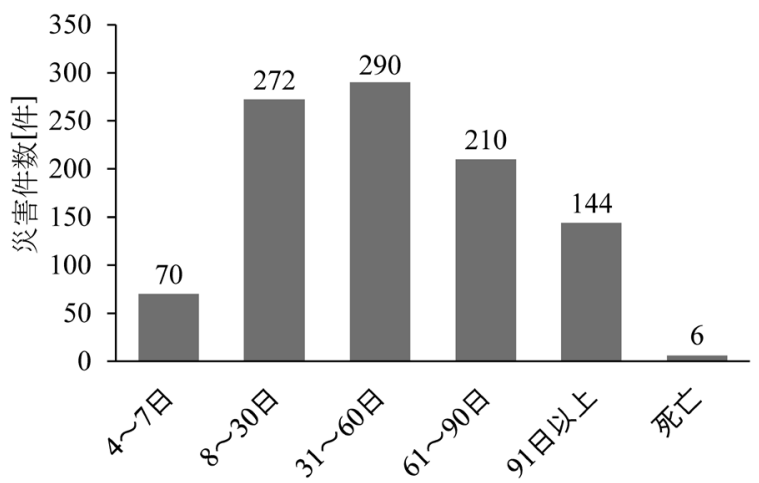

図2 休業見込日数の日数別の構成比

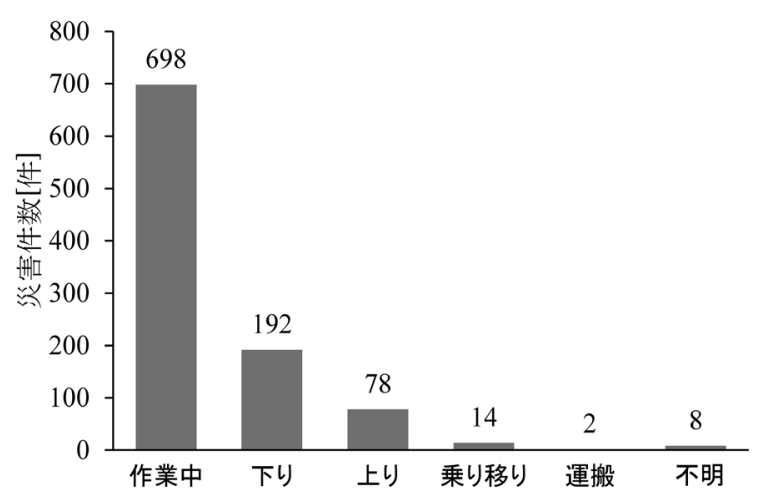

図3 災害発生状況の種類別の構成比

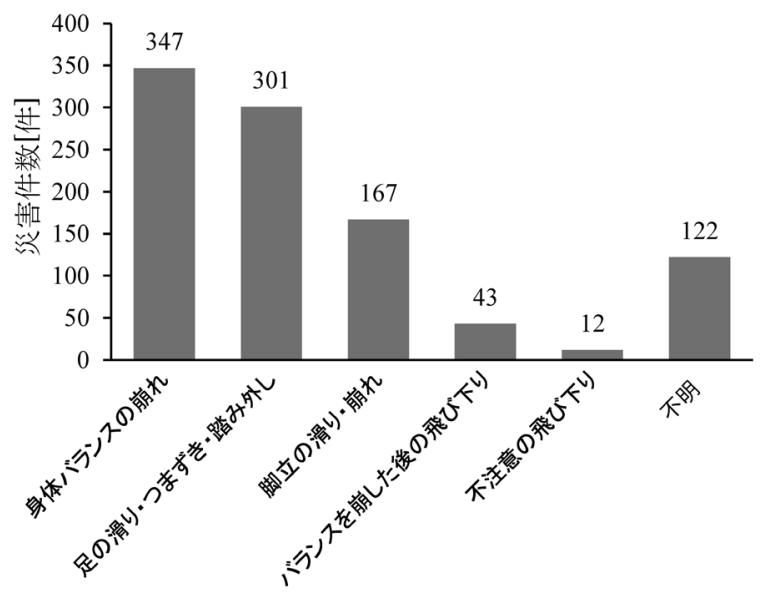

図4 災害のきっかけの種類別の構成比

と考えられる.

次に, どのような状況下で災害が発生しているかに ついて調査した結果を図3に示す。「作業中」は脚立上 に立って作業している最中，「上り」は脚立を上る最中， 「下り」は脚立を下りる最中, 「乗り移り」は脚立と屋根 などの移動中,「運搬」は脚立の持ち運び中をそれぞれ示 す.この結果を見ると, 脚立上で作業中の事故が最も多 く, 全体の 70\%以上を占めていた. 次に多いのは下りで 約 $20 \%$, 上りは約 $8 \%$ 程度であった.

図4の事故のきっかけの内訳をみると, 最も多いのは 身体バランスの崩れ (35.0\%) で, 次に足の滑り・つまず き・踏み外し $(30.3 \%)$, 脚立の滑り・崩れ (16.8\%) と 続いていた。作業者の姿勢の崩れと脚立の崩れに大別す ると, 先の 2 項目は姿勢の崩れに含まれ, 全体の $65 \%$ 以
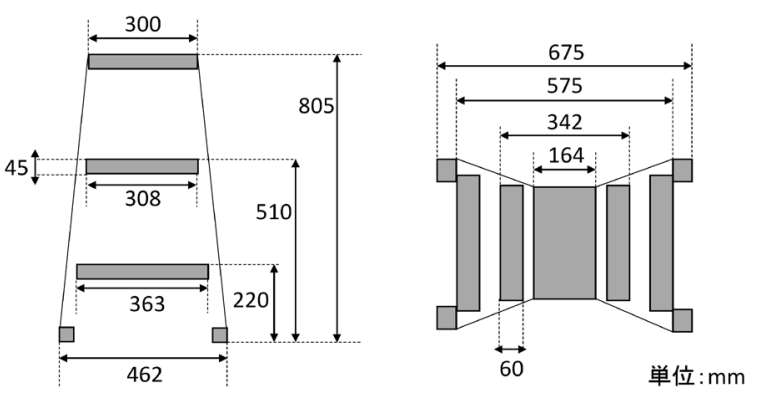

図 5 使用した脚立の寸法

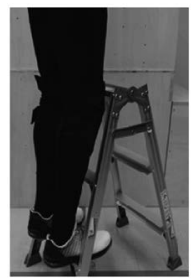

天板の2段下

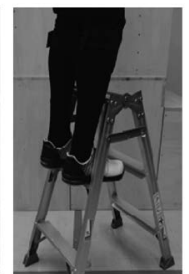

天板の1段下 天板のまたぎ

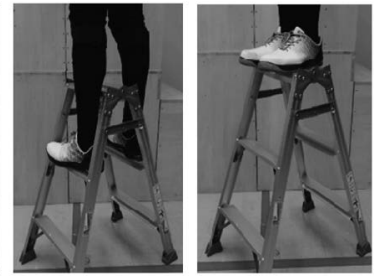

天板
図6 脚立への立ち方条件

上を占めていた。そのため, 脚立起因災害を防ぐために は，身体バランスの崩れや足の滑り・つまずき・踏み外 しなど, 姿勢の崩れを防ぐことが重要であると考えられ る.

\section{3 脚立への適切な立ち方に関する実験研究 ${ }^{4)}$}

脚立起因災害の発生状況では, 作業中に身体のバラン スを崩し転落するパターンが最も多い傾向にあった。そ こで, 脚立上での作業姿勢のバランスが崩れる原因の一 つとして脚立への不適切な立ち方があると考え, 脚立の 立ち方が姿勢バランスに与える影響について作業を模擬 した実験により検討することとした。

\section{1) 実験概要}

実験は 20 代の男性 10 名を対象として行った。実験課 題は, 図5に示す寸法の3段脚立に立った状態で, 手を 伸ばすことができる最大の距離 (以下, 最大リーチ距離) を計測するものである，具体的には，脚立上に立ちなが ら, 片腕を指示された方向に挙上し, 合図とともに前方 に身体を傾け，その傾けた姿勢を5 秒保持するというタ スクである. その際，人差し指先端に取付けたマーカ位 置を測定し, 水平面上で脚立の中心からの水平距離を 算出し, 最大リーチ距離と定義した。 また，3軸ロード セルが四隅に内蔵されたフォースプレート（Kitsler社, 9286BA）を脚立の下に2枚並べて設置し, 脚部に加わる 荷重を測定した。その後フォースプレートの中心軸まわ りのモーメントを鉛直方向の力で除した值を床反力作用 点と定義した.

実験条件は脚立への立ち方と, リーチ方向（手を伸ば す方向）をそれぞれ変化させた．脚立への立ち方は図6 に示すように, 天板の2段下, 天板の 1 段下, 天板のまた ぎ, 天板の 4 条件とした.リーチ方向は参加者の利き腕 側の肩を基準に, 前方を $0^{\circ} と し$, 左 $90^{\circ}$, 左 $45^{\circ}, 0^{\circ}$, 右 $45^{\circ}$, 右 $90^{\circ}$ の 5 条件とした。 なお, 腕を挙上する高さは 
実験参加者の肩峰高とし，身体を傾けても同じ高さに維 持するよう指示した．また，もう片方の腕は脚立に触れ させず身体に沿わせるように指示した。なお本実験は労 働安全衛生総合研究所の倫理審査委員会の承認を得て実 施した。

\section{2）姿勢の安定性の評価方法}

脚立上での姿勢安定性を評価するため, 人の姿勢のバ ランスについて考える.はじめに, 人が床の上に静かに 立っている場合, 身体は完全に静止しているように見え ても身体の重心は前後左右に細かく摇孔続けている．こ れは図7-11のように，人の身体に作用する重力と，床 から押し返される床反力の関係によって説明される. 重 力の作用によって身体は回転しようとするが, 床反力に よって逆向きに回転させる力を得ることで立位の状態を 保っている. 通常の立位の場合, 床反力を受ける点（床 反力作用点）は足裏の範囲であれば移動でき，その範囲 は支持基底面と呼ばれる。 もし身体の重心がこの支持基 底面より外側に出てしまうと, 足を一歩踏み出すなどし ない限り姿勢を立て直すことが困難となり, 姿勢が不安 定な状態となる。

次に, 脚立の上では踏ざんの上に立つため, 図7-(2) のように床反力は踏ざん幅の分だけしか移動できなくな る.この状態では身体が少し傾いただけで重心はすぐに 踏ざんより外側に出てしまうため, より細かなバランス コントロールが必要となる。 さらに, 床の上では倒れる 前に足を一歩踏み出せばよいが, 脚立の上では足を踏み 外してしまうため一度も重心を支持基底面より外側に出 さないことが求められる.

以上のことから, 姿勢のバランスを安定させるために は床反力の移動範囲を広く保つことが重要となる．そこ で支持基底面が作業中の身体の重心移動に対して十分に 広い範囲を持っているかどうか， 4 種類の脚立への立ち 方について比較を行った.

\section{3）実験結果と考察}

脚立の上に立った状態で水平方向に最大限遠くまで手 を伸ばした際の, 床反力作用点の最大移動距離と最大 リーチ距離について, 10 人分の平均值と標準偏差を図 8 に示す. なお, 各立ち方条件の值は全リーチ方向の平均 值である.

この結果をみると, 天板の 2段下での移動距離が最も 大きくなったのに対し，天板での移動距離が最も小さ く, 天板の 2 段下より $50 \%$ 減少していた。 また, 最大 リーチ距離の結果をみると, 天板の $2 \mathbf{E}$ 下条件と天板条 件間に有意差はなく, どちらも脚立の中心から $105 \mathrm{~cm}$ 程度まで指先が伸びることが示された。これは, 天板の 2段下に立つと上段の踏ざん側面に下肢を接触させるこ とができるため, 脚立に体重をかけて身体を支えること ができるためだと考えられる，そのため天板の2段下の ほうが天板に立つよりも身体を傾けることができ, 結果 としてリーチ距離についても天板条件と同程度に手を伸 ばすことができたと考えられる.

これらのことから, 前方に手を伸ばすような作業にお
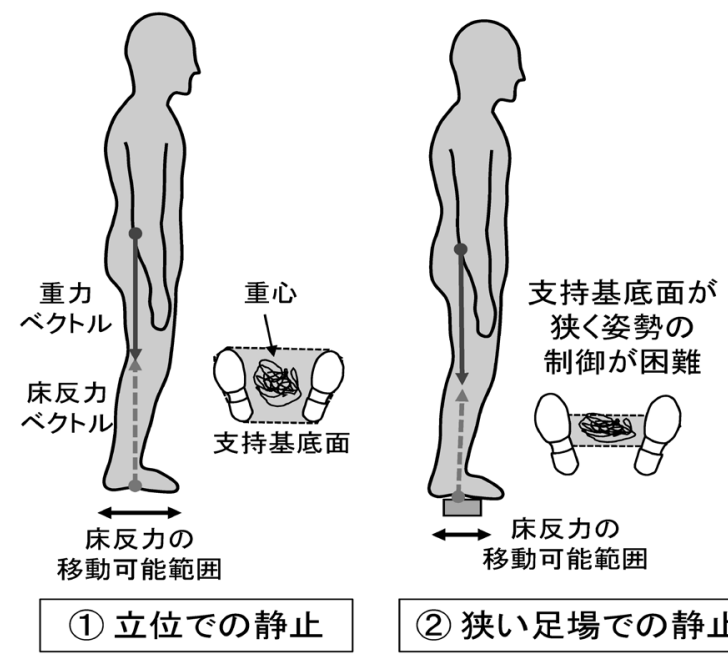

移動可能範囲

(2) 狭い足場での静止

図7 姿勢のバランス保持のイメージ

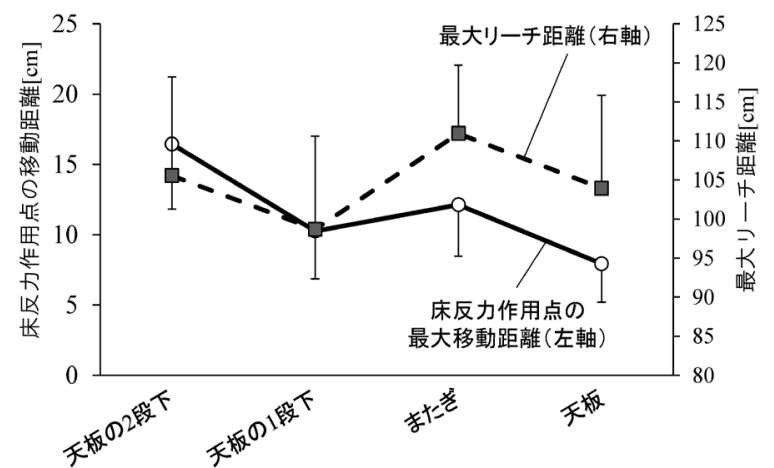

図8 脚立への立ち方による床反力作用点の移動距離と最大リー 千距離の比較

いては，天板の 2 段下に立って作業する場合が 4 種類の 立ち方のなかでは作業姿勢が安定すると考えられる。実 際の作業現場では, 持ち運びやすさを優先して低い脚立 を選び，その天板に立って作業する場面が多く見られる が, これでは姿勢が不安定になるため, 少し大きめの脚 立を選び，上段を余らせながら使用することが重要であ ると考えられる.もともと，ほとんどの脚立では天板に 立って作業することが禁止されているが, 姿勢が顕著に 不安定になると予想されるため, このルールを遵守する 必要がある.

\section{4 脚立の適切な使用方法に関する提言}

脚立作業中の転落災害は, 主に脚立自体が倒れるか, 作業者のバランスが崩れることによって発生する，その ため, これらの事象を発生させないための取り組みが重 要となる。また，仮に上記の事象が発生した場合に被害 の重篤化を防ぐため, 保護具の利用も重要となる. 以下 では実際の作業における注意点について述べる.

\section{1）用具の選択}

はしご兼用脚立は，はしごとしても使用できる便利さ から作業現場で使用されることが多い用具であるが, 安 全性については必ずしも十分とは言いがたい，その理由 は, はしご兼用脚立の踏ざんが $4 \sim 6 \mathrm{~cm}$ 程度と狭く作業 姿勢が不安定になりやすいためである。また，上枠もな

Vol. 10, No. 1, pp. 55-58, (2017) 
いため手で体を支えたり，バランスを崩した際に寄りか かったりすることができない，そのため，はしご兼用脚 立を使用する特別な理由がない場合は，上枠付き専用脚 立や高所作業台, 可搬式作業台などを用いることが望ま しい.これらの用具には乗ることのできる広いステップ があり，上り下り時の踏ざんも広く設計されている。 ま た，上枠があるためバランスを崩しても体を支えること ができるなど安全性に関してははしご兼用脚立より優 れていると考えられる．ただし，はしご兼用脚立と比較 すると大型で重いものが多いため, 作業中に脚立を移動 する頻度や作業場が狭い場合は使いにくいことが想定さ れる. 作業現場の特徴に合わせた用具を選ぶ必要がある が，「脚立」だけでなく「作業台」や「足場台」などの類 似する用具も選択対象に入れ，できるだけ広い踏ざんま たは作業床のある用具を選択することが望ましい.

\section{2）設置，設備点検}

止め具が外れていたり, 脚部が故障したまま使用する と, 脚立自体が倒れたり崩壊する災害につながることが 想定される．また，軟弱な地盤の上に脚立を設置する と, 作業中のわずかな体重移動で急に脚立自体が不安定 になることがある．脚立を設置しただけでは倒れない が，そこに作業者が上り荷重が加わることで転倒につな がるケースは多いため十分な注意が必要である. 脚立の 設置場所や設備点検を十分に行い, 脚立を上る際や作業 中の災害を防止することが必要となる。

\section{3）作業姿勢}

脚立上で作業を行う際に特に注意すべきことは, 身体 の重心が脚立の支持基底面から外に出るような, 身を乗 り出す姿勢をとらないことである. 物品を持ち上げるた めに手を伸ばしたり, 工具の使用中に体を乗り出すこと は作業者の姿勢を不安定にするとともに脚立自体も倒れ やすくする. また, 重量物の持ち上げや反動を受ける作 業, 上向き姿勢も転落リスクを高死考えられる. 物 品の上げ下ろし, 壁面への釘打ち, 空の清掃, 蛍光灯の 交換, 樹木の剪定などの作業は多くの業種に共通してい るが, 脚立上で無理な姿勢をとらずいったん脚立を降り て脚立の位置を調整しなおすことが大切である.

また，バランスを崩しても脚立に寄りかかれるような 姿勢で作業することも大切である. そのためには, 最上 段（天板）から少なくとも2段下の踏ざんに立つことが 望ましい，そうすることで太ももから腰周辺を踏ざんの 側面に接触させることができ, 姿勢の安定化につなが る. 天板の 1 段下では, 脛や膝が軽く接触するだけで十 分に体を支えることができず，姿勢を安定させる効果は 少ないため注意が必要である. 作業現場では, 作業者が
持ち運びの簡便な低い脚立を選び天板等に立って作業す る場面がたびたび見受けられるが, 安全な脚立作業のた めには少し高めの脚立を選択し上段を余らせながら使用 することが望ましい.

天板をまたいで作業する場合は，作業姿勢は安定する が脚立自体が転倒しやすいため注意が必要となる。多く の脚立は, 昇降面が地面と75度の角度をなしているの に対し, 左右方向は 85 度と垂直に近いため倒れやすく なっている. 脚立自体の転倒防止には，アウトリガーと 呼ばれる器具を装着し，左右方向への傾きをつけること が有効となる。

\section{4）墜落防止措置と保護具}

万が一脚立からバランスを崩してしまった際に備え, 墜落防止装置と保護具を利用することは災害防止や被害 の軽度化に重要である. 特に, 死亡災害の多くは頭部を 負傷していることから，使用する脚立の高さにかかわら ず保護帽を身につけて頭部の負傷を防止することが大切 であると考えられる。 また作業現場に親綱を張ることが できれば，フルハーネス安全帯を使用することが望まし い. ただし客先での脚立使用時などは安全帯を使用する ことができないため, 作業環境に応じて適切な墜落防止 措置を講じることが必要となる。

\section{5 おわりに}

脚立作業を行う前提として, 脚立は転落リスクが高い 用具であるという認識を持ち作業することが大切であ る. 高所作業をせざるを得ない場合, 脚立の他に安定し た用具を使うことができないか事前に検討することが重 要となる。また，作業前には開き止めや床面の確認を行 い脚立自体が倒れないようにすること，作業中には適切 な作業方法によって作業者がバランスを崩さないように することにそれぞれ十分に気を配る必要がある. 脚立上 ではバランスを崩すと即転落につながってしまうという 意識を持ち, 多方面から作業の安全性について検証する ことが必要である.

\section{文献}

1）JIS S1121: 2013. アルミニウム合金製脚立及びはしご.

2）菅間敦，大西明宏．脚立に起因する労働災害の分析．労働 安全衛生研究. 2015; 8(2): 91-98.

3）厚生労働省：職場の安全サイト，労働災害（死傷）データ ベース. http://anzeninfo.

4）菅間敦，大西明宏。最大リーチおよび作業姿勢の評価によ る脚立への安定した立ち方の検討. 人間工学. 2016; 52(1): 40-48. 